УДК 616.717/.718-001.5-089.2(045)

DOI: http://dx.doi.org/10.15674/0030-59872019157-63

\title{
Tactical treatment optimization for long bone distal metaepiphysis fractures based on biological principles
}

\section{G. Bets}

Sytenko Institute of Spine and Joints Pathology National Academy of Medical Sciences of Ukraine, Kharkiv

The intensive development of orthopaedics and traumatology has led to the appearance of problematic issues in the treatment of fractures of distal metaepiphysis of long bones (FDM). The reason to divide them out from the whole array of intraand near-articular fractures was the commonality of classifying characteristics (according to AO classification). Objective: to improve the results of treatment of FDM fractures based on the use of well-grounded tactical decisions in accordance with biological principles. Material and Methods: A retrospective study was made; we analyzed medical records of 122 patients. Prospective study included - 217 patients, where we applied the optimized therapeutic fracture therapy. We have done an experimental study for 13 patients with studying of tibia fragments mobility fixed with one-side rod fixators with specially developed equipment. Another one experimental «in vivo» study was made on 28 rats, who received standardized fractures of lateral femur condyle. The physical properties of the Softcast and Scotchcast braces, the properties of these materials and external fixing devices were investigated by mathematical modeling. Results: in the retrospective group of patients with FDM injuries methods of internal fixation were prevailed - $59 \%$, external fixation was used in $22 \%$ of cases, conservative treatment - in $19 \%$. Failed results (32\%) were due to the development of complications, $25 \%$ of which were infections, $7 \%$ regeneration disorders. In the prospective group, the proportion of conservative methods was $29 \%$, external fixation - $50 \%$, internal $-21 \%$. The change in the treatment method for FDM injuries has been substantiated by the results of experimental studies. Conclusions: the tactics for treatment of FDM were optimized based on biological principles and functional remodeling, which allowed to increase the number of good results up to $58 \%$ (against $44 \%$ in the retrospective group) and reduced the number of unsatisfactory results to $9 \%$ (compared to retrospective group $32 \%$ ). Key words: distal metaepiphysis, fracture, treatment, functional remodeling effect, clinical-experimental study, biological principles

(C) Bets I. G., 2019
Інтенсивний розвиток ортопедії та травматології привів до виникнення проблемних питань у лікуванні переломів дистальних метаепіфізів довгих кісток (ДМЕДК). Підставою виділити їх із масиву внутрішньо- та навколосуглобових ушкоджень була спільність класифікаційних ознак за АО. Мета: покращити результати лікування переломів ДМЕДК на підставі використання обтрунтованих тактичних рішень відповідно до біологічних принципів. Методи: проведено ретроспективне дослідження з вивчення медичної документації 122 пацієнтів і проспективне - 217 постраждалих, в яких застосовано оптимізовану лікувальну тактику переломів ДМЕДК. Проаналізовано взаємну рухомість відламків великогомілкової кістки, фіксованих однобічними стрижневими апаратами у 13 пацієнтів. Експеримент «іn vivo» проведено на 28 щурах, яким моделювали стандартизовані переломи суглобової поверхні зовнішнього виростка стегнової кістки. Методом математичного моделювання досліджено фізичні властивості opmезів із Softcast i Scotchcast, якості иих матеріалів та апаратів зовнішньої фіксації. Результати: у ретроспективній групі хворих із ушкодженнями ДМЕДК домінували методи внутрішньої фіксації - $59 \%$, зовнішню фіксацію використано у 22 \% випадків, консервативне лікування в $19 \%$. Незадовільні результати (32\%) обумовлені розвитком ускладнень, із яких $25 \%$ були пов'язані з інфекиією, $7 \%$ - із порушеннями регенерачії. У проспективній групі частка консервативних методів становила $29 \%$, зовнішньої фіксачї - 50 \%, внутрішньої - $21 \%$. Зміну тактики лікування ушкоджень ДМЕДК обтрунтовано результатами експериментальних досліджень. Висновки: оптимізовано тактику лікування ушкоджень ДМЕДК на підставі біологічних принципів та функиіонального ремоделювання, використання якої дало змогу підвищчити кількість добрих результатів до $58 \%$ (проти $44 \%$ у ретроспективній групі) та зменшили кількість незадовільних результатів до $9 \%$ (проти $32 \%$ ). Ключові слова: дистальний метаепіфіз, перелом, лікування, ефект функиіонального ремоделювання, клініко-експериментальне дослідження, біологічні принципи. 
Key words: distal metaepiphysis, fracture, treatment, functional remodeling effect, clinical-experimental study, biological principles

\section{Introduction}

Intensive development of the national orthopaedic and traumatological science during the last decade naturally has led to the emergence of numbers problematic issues related to the treatment tactics and technologies of traumatic long bones injuries. One of this period characteristics is a wide use of active surgical technologies developed by the Association Osteosynthesis (AO) [1-4]. These techniques have brought to a new level and significantly expanded possibilities of surgical treatment bone fractures. However, this process also had negative consequences. Primarily, it concerns a threatening number of complications which reach $54 \%$ at some localizations of intra-articular and near-articular fractures (Pilon fractures) [5-14]. This circumstance determines the relevance of this study. The object of this research is long bone distal metaepiphysis fractures (LBDMF). The reason for singling them out from the whole array of intraarticular and near-articular fractures (which constitute the main problem of fracture treatment) was the commonality of classifying characteristics (neararticular, partly intra-articular and intra-articular according to the AO classification). This cannot be said about proximal bone metaepiphysis fractures. In turn, the commonality of the classifying characteristics of LBDMF determines the similarity of tactical and technological treatment approaches [15-25].

The comparison of a significant number complications (primarily infections) with a dominant share of aggressive internal fixation technologies allowed to conclude that indications for ORIF were ungrounded in many cases [10, 26-31]. First of all, it led to the neglect of osteosynthesis biological principles (which AO developers emphasize): an additional surgical trauma would place heavily injured tissues outside of viability [32-34]. Secondly, the task of internal fixation can be considered accomplished only after an anatomical reposition and a secure fixation of bone fragments have been achieved. It excludes the need for a further additional immobilization and assures a possibility of an early functional treatment. Such possibilities are very uncertain, for example, in cases of intraarticular multifragmentary impression fractures. However, such conditions were not taken into account during the presurgical planning [32-35].

Thus, the absence of precise and well-grounded criteria for selecting the LBDMF methods of treatment led to tactical errors and a significant number of severe irreversible complications. The methods of external fixation are known as reliable means of infection complications prevention in open highenergy trauma cases. There is no question as to their compliance with osteosynthesis biological principles, which allows to regard such technologies as an alternative to the internal fixation [10, 21, 26, 33, 34].

At the same time, there are unresolved fundamental questions of the problem of external osteosynthesis, such as the optimal rigidity of relative mutual fixation and the effect of the relative mobility of bone fragments on the reparative process. A stimulating effect of bone fragments relative mobility to the reparative process was considered as axiom in scientific literature for many years $[12,16-18,28,34]$. However, what are the amplitudes of displacement which separate the stimulation of bone regenerate development from its destruction? Does it depend on the localization and the stage of the reparative process? These issues appear to be extremely important. Their solution can contribute to a more meaningful use of methods and tools for non-osteosynthesis procedures as well as to creating conditions for regulating the reparative process.

Objective: to improve treatment results for long bone distal metaepiphysis fractures by using well-founded tactical decisions based on biological principles.

\section{Material and methods}

Experimental study is approved by the bioethics committee of Sytenko Institute of Spine and Joint Pathology (report № 162, 06.03.2017). The first stage was a retrospective clinical study based on the archival material of three specialized departments in the Kharkiv city with the goal to establish real quantitative and qualitative correlations of technologies applied in the LBDMF treatment, its outcomes and complications. The analysis of medical records of 122 patients indicates the domination of the open reposition and internal fixation (ORIF) in the LBDMF treatment (59\%). External fixation technologies come second and are used in $22 \%$ of cases. In addition, treatment methods of intra-articular and neararticular fractures, which are considered outdated or mere historical significance (fixation method and skeletal traction) are used in $19 \%$ of cases. The results of the application such tactical and technological approaches in LBDMF treatment are as follows: good - $44 \%$; satisfactory $-24 \%$; unsatisfactory $-32 \%$. Unsatisfactory treatment results were due to complications, $25 \%$ of which were infections and soft tissue necrosis, and $7 \%$ were regeneration defects (nonunion) and significant limitation of joint function. 
The biomechanical study was conducted on the specially developed stand and recording equipment, as well as with the participation of 13 patients who gave their informed consent. It was studied the relative mobility of the tibia bone fragments fixed with onesided rod fixators in clinical conditions.

The functional remodeling effect was discovered «in vivo» experiment. For histological specimen examination of standardized traumatic impression fractures we have performed murine experimental study (28 rats). These injures were performed a specially developed traumatic device. The animals would then be taken out from experiment at 3, 7, 14 and 28 days after fracture.

The mathematical modeling method was used to study of the physical properties of Softcast and Scotchcast materials, which we used later on for functional orthoses for LBDMF treatment. We have researched the orthoses properties like an external fixation devices and possibility of their adequacy to the clinical requirements.

The main clinical study group (prospective study) has included 217 patients with LBDMF. There are the following proportions for treatment technologies: fixation method - $23 \%$, skeletal traction $6 \%$, external fixation - $50 \%$, internal fixation $21 \%$. As a result of such a tactical and technological approach there were achieved $58 \%$ good results, $30 \%$ satisfactory and $9 \%$ unsatisfactory results. Overall it constitutes $97 \%$ of the originally planned number of patients. Six patients left the study.

\section{Results}

Realizing the complexity solution of all the abovementioned issues, we have determined to solve at least part of them. The first one retrospective clinical study based on analytic result of medical records 122 patients. There are 24 patients had fractures in the 1.3 localization, 20 - in the 2.3 localization, 26 in the 3.3. localization, and 43 - in the 4.3 localization. The application of each technology in this study group had the following percentage: fixation method - $16 \%$, skeletal traction - 3\%, external fixation $-22 \%$, internal fixation $-59 \%$. The results of the application such tactical and technological approaches in the LBDMF treatment are as follows: good $-44 \%$; satisfactory $-24 \%$; unsatisfactory $-32 \%$. The comparison of a significant number complications (primarily infections) with a dominant share of aggressive internal fixation technologies allowed to conclude that indications for ORIF were ungrounded in many cases.
At the experimental studies we have researched the relative mobility of the tibia bone fragments fixed with one-sided rod fixators in clinical conditions. The study was conducted with the help of a specially developed stand and recording equipment, as well as with the participation of 13 patients who gave their informed consent. As a result of this work, we received graphs reflecting the dynamics of «pre pain» loads and the amplitude of tibia bone fragments dislocation in the regeneration process. Conceptually, it is suggested that pain in the fracture zone can serve as a criterion for the marginal non-destructive load on the regenerate. During the first 6 weeks of treatment under «pre pain» load influence to the bone regenerate, the dislocation amplitude of tibia fractures decreased from $(2.3 \pm 0.2) \mathrm{mm}$ to $(0.8 \pm 0.2) \mathrm{mm}$, and the magnitude of the «pre pain» load increased from $(210 \pm 1.5) \mathrm{H}$ to $(751 \pm 1.5) \mathrm{H}$. It has been established that conditions for an adequate training of the bone regenerate by the application longitudinal axial loads without secondary fragment dislocation risk can be achieved with fixation devices of adjustable rigidity, though the load on the regenerate can also be significantly adjusted by using devices that do not include mechanisms for regulating rigidity. The obtained data on the dynamics of «pre pain» loads and relative fragment displacements can form the basis for developing the methods of impacting the regeneration process. In addition, the newly obtained knowledge allowed to make preliminary conclusions on the conformity of different rod fixators constructions to specific clinical requirements.

In the course of clinical studies, it was observed that residual displacements of the articular surface fractures («steps») radiologically «align», disappear, and do not clinically manifest over time under certain conditions of the rehabilitation treatment. Having established it empirically in clinical conditions, we called this phenomenon a functional remodeling of the articular surface. It was conceptually suggested that the reasonable use of this phenomenon may significantly compensate for the deficit of extraosseous osteosynthesis methods reposition abilities. However, it was necessary to find out how long it would take for the bone regenerate, whose morphological properties would optimally assure the effect of a functional remodeling, to be formed in the area of the intraarticular fracture after a trauma (surgery). For this purpose we have performed «in vivo» experimental study on animals (rats), which received standardized traumatic impression fractures. These injures were performed a specially developed traumatic device. The animals would then be taken out from experiment 
at different times after the fracture, and injured zones were studied histomorphologically. The formation of a certain cellular composition of the regenerate (which suggests its certain physical qualities) gave an idea of the reasonable optimal time terms for the beginning of a functional remodeling.

It is clear that the developed tactics and technology of the LBDMF treatment should be supported with means of therapeutic immobilization and functional orthosis, which are adapted to specific clinical and technological tasks. For this purpose, we have performed biomechanical studies of the physical properties of Softcast and Scotchcast materials, which we used later on for functional orthoses. We have researched the orthoses properties like an external fixation devices and possibility of their adequacy to the clinical requirements in the LBDMF treatment with the mathematical modeling method.

Prospective clinical studies formed the most significant component of the research aimed at tactical treatment optimization for LBDMF. The main (prospective) clinical study group consisted of 217 patients. There were 34 patients with fractures of the 1.3 localization, 100 patients with fractures of the 2.3 localization, 41 patients with fractures of the 3.3 localization, and 42 patients with fractures of the 4.3 localization according AO classification. There are the following proportions for treatment technologies: fixation method - $23 \%$, skeletal traction - $6 \%$, external fixation $-50 \%$, internal fixation $-21 \%$. As a result of such a tactical and technological approach in the prospective group there were achieved 58\% good results, $30 \%$ satisfactory and $9 \%$ unsatisfactory results. Overall it constitutes $97 \%$ of the originally planned number of patients. Six patients left the study.

In a subgroup of 34 patients with LBDMF, the fixation method was used in $11 \%$ of cases, skeletal traction - in $14 \%$, external fixation - in $29 \%$, internal fixation - in $38 \%$ of cases. $8 \%$ of patients from this subgroup were dropped out. This tactic allowed to receive $40 \%$ of positive results of treatment, $40 \%$ were satisfactory, and $12 \%$ were unsatisfactory. The characteristic of these fractures is that an anatomical reposition and a reliable fixation of bone fragments can be achieved mainly due to ORIF, though this task is rather difficult, and the surgical intervention is quite traumatic.

Distal radius and ulna metaepiphysis fractures are localization which produced a high percentage of good treatment results with using of distraction ligamentotaxis by external fixation devices $[36,37]$. Finally in our study, this technology was used in $45 \%$ cases of 2.3 localization. The characteristic is that the external fixation was effective with type $\mathrm{C}$ fractures, where the fixation method and even ORIF have very doubtful perspectives of acceptable results. Therefore, the fixation method is applied in $38 \%$ patients and internal fixation - in $17 \%$ in this study subgroup (the total of 100 patients). Such correlation of applied treatment technologies allowed to receive $73 \%$ good results, $21 \%$ satisfactory and $6 \%$ unsatisfactory results.

The subgroup of femur distal metaepiphysis fractures included 44 patients. In this subgroup, the fixation method was used in $5 \%$ of cases and gave satisfactory treatment results. A rather high number of patients $(20 \%)$ were treated by the skeletal traction method. External and internal fixation were used proportionally and constituted 32 and $36 \%$ respectively. Treatment technics used in the abovementioned proportions provided for $32 \%$ of good results, $43 \%$ of satisfactory and $18 \%$ of unsatisfactory results. We didn't get follow-up for 3 patients (7 \%) from this subgroup because they have left study.

The study group called «Tibia distal metaepiphyses (pilon) fractures» consisted of 42 patients, 12 of whom had type A fractures, 14 - type B, and 16 - type $C$ fractures. 15 of 42 patients in this study group had open fractures and received surgical treatment amounting to an urgent radical surgical treatment of wounds, and an external fixation with onesided rod fixators in one step. A two-step approach in treating closed pilon fractures was used on the patients undergoing a consistent skeletal traction during the first 1-3 days. This step was introduced for examining and (important) for presurgical planning using a distraction X-ray test. There were received $67 \%$ good treatment results, $28 \%$ satisfactory and $5 \%$ unsatisfactory results.

At the final stage of clinical trials, we conducted a comparative assessment of LBDMF treatment results for patients from the retrospective and the prospective groups, taking into account the tactics and treatment technology used on the patients in both groups. Comparing the data of the use of various technologies for the treatment of LBDMF in both study groups, it became evident that the proportion of conservative methods of treatment (fixation method and skeletal traction) increased from 19 to $29 \%$. The ratio of the external and internal fixation has changed most significantly: in the retrospective clinical trial group, this proportion was 22 and $59 \%$, and in the main clinical trial group this ratio was 50 and $21 \%$, respectively. 
Such changes in tactical and technological focus made it possible to increase the number of good results from 44 to $58 \%$ and satisfactory results from 24 to $30 \%$. The number of unsatisfactory results decreased from 32 to $9 \%$. It is obvious that this was the result of a careful consideration of the internal fixation technologies. During the presurgical planning and taking into consideration the entire complex patients and fractures characteristics, the decision to perform a traumatic and dangerous surgery was taken only when a clear perspective of a quality and reliable internal fixation justified all the risks.

The methods of external fixation which were used alternatively proved to be reliable means to prevent of infection complications after open fractures as well as safe in the treatment of high energy LBDMF. The repositioning capabilities of external osteosynthesis, which can be inferior in comparison to ORIF technologies (important for intra-articular fractures), can be largely compensated with functional remodeling of joint surfaces.

\section{Discussion}

Quantitative and qualitative correlations of current technologies for LBDMF and clinical results of their application are established for the first time. The scientific knowledge correlation between the means of immobilization and functional orthosis to the tasks of the LBDMF treatment was supplemented with the use of the biomechanical study. The functional treatment terms which are optimal to assure the effect of the functional fractures remodeling joint surfaces were substantiated for the first time based on the experimental data. Form-producing abilities of the joint surfaces fractures functional remodeling were studied experimentally and substantiated clinically. Specific scientific data on mutual mobility of bone fragments and biological consequences of this phenomenon were obtained in clinical conditions.

The modern tactical LBDMF treatment optimization principles with the use of biologically justified technologies were supplemented with the conducted clinical trials. Experimental and clinical studies results allow to focus practical recommendations for the tactics and technology for LBDMF treatment.

Responsible consideration to use ORIF should follow a careful presurgical planning during which one must consider both the formal fractures classification and the individual fractures characteristics, such as:

- energy of the fracture and risk to loss a viability of the injured musculoskeletal system segment;

- technical possibilities and guaranteed perspectives of successful application selected internal fixa- tion method with consideration bone fragments number and size, the presence posttraumatic impression components, and the severity of soft tissues damage;

- general patient's condition, the presence of concomitant pathology and probability of life-threatening complications;

- patient's motivation degree and possibility of effective cooperation with him in the treatment care process.

A careful analysis of the above-mentioned indicators can assure a justified responsible decision for use of such effective, though traumatic and dangerous, treatment technologies as ORIF.

\section{Conclusions}

To reach the goal of internal fixation (anatomic reposition, rigid fixation in compliance with the biological principles) can become doubtful should the above-mentioned factors of presurgical planning be ignored. Uncertainty in fixation forces reliability one to use additional means of immobilization and to begin the functional rehabilitation much later, which gives the results not better than those with nonsurgical treatment (while maintaining the complications risk). The external fixation methods, which comply with the fractures treatment biological principles and reliably prevent infection complications, should be the first to apply with doubtful perspectives of the ORIF results.

One must pay close attention to the functional treatment within the terms which are optimal to secure a functional remodeling effect of injured joint surfaces (2-4 weeks after the trauma) while treating intraarticular LBDMF complications. Functional orthoses must be used at the stage of a functional rehabilitation in order to prevent secondary bone fragments dislocation.

The nonsurgical treatment methods like a skeletal traction procedure should not be ignored. They can become the methods of a forced choice for inoperable and asocial patients and assure acceptable treatment results in a significant number of cases. Special attention should be paid to an early functional treatment. The early functional treatment procedures must be assured with adequate means of functional orthoses in order to nullify secondary fragments dislocation danger.

Results of this clinical-experimental study is very promising because tactic of using biological principles have increased the number of good treatment results from 44 to $58 \%$, satisfactory results from 24 to $30 \%$ and these treatment principles 
decreased general complication rate after LBDMF from 32 to $9 \%$.

Conflict of interest. The author declare the absence of conflict of interest.

\section{References}

1. Factors associated with the development of early infection aftersurgical treatment of fractures / J. E. Alcantara, R. A. Aguiar, J. G. L. Sampaio [et al.] // Acta Ortopédica Brasileira. - 2018. - Vol. 26 (1). — P. 22-26. DOI: $10.1590 / 1413-785220182601173883$.

2. Ali F. Treatment of distal femoral nonunions by external fixation with simultaneous length and alignment correction / F. Ali, M. Saleh // Injury. — 2002. - Vol. 33 (2). - P. 127-134.

3. Anderson D. D. The pathomechanical etiology of post-traumatic osteoarthritis following intraarticular fractures / D. D. Anderson, J. L. Marsh, T. D. Brown // The Iowa Orthopaedic Journal. - 2011. - Vol. 31. - P. 1-20.

4. Ilizarov external fixation for severely comminuted supracondylar and intercondylar fractures of the distal femur / M. Arazi, R. Memik, T. C. Ogun, M. Yel // The Journal Bone and Joint Surgery. Br. - 2001. - Vol. 83 (5). - P. 663-667.

5. Bagaria V. Distal Femoral Fractures: Complications and How to Avoid them? / V. Bagaria, S. Shah, G. Sharma // Trauma International. - 206. - Vol. 2 (1). - P. 24-27.

6. Beaman D. N. Fracture reduction and primary ankle arthrodesis: a reliable approach for severely comminuted tibial pilon fracture / D. N. Beaman, R. Gellman. // Clinical Orthopaedics and Related Research. - 2014. - Vol. 472 (12). P. 3823-3834. - DOI: 10.1007/s11999-014-3683-x.

7. External fixation of distal femoral fractures in adults' multicentre retrospective study of 43 patients / L. Bedesa, P. Bonneviallea, M. Ehlingerb [et al.] // Revue de Chirurgie Orthopédique et Traumatologique. - 2014. - Vol. 100 (8). - P. 623-627.

8. Medium-long-term radiographic and clinical outcomes after surgical treatment of intra-articular tibial pilon fractures by three different techniques / C. Biz, A. Angelini, M. Zamperetti [et al.] // BioMed Research International. — 2018. — Vol. 2018. Article ID: 6054021. — DOI: 10.1155/2018/6054021.

9. Bonnevialle P. Operative treatment of early infection after internal fixation of limb fractures (exclusive of severe open fractures) / P. Bonnevialle // Orthopaedics \& Traumatology : Surgery \& Research. — 2017. — Vol. 103 (1S). — P. 67-73. DOI: $10.1016 /$ j.otsr.2016.06.019.

10. Infected nonunion of the humerus treated with an antibiotic cement rod. Case report / G. Gallucci, A. Donndorff, J. Boretto [et al.] // Chirurgie de la Main. — 2007. - Vol. 26 (4-5). P. 242-246. — DOI: 10.1016/j.main.2007.07.006.

11. Gaulke R. Tibial pilon fractures: Advoidance and therapy of complications / R. Gaulke, C. Krettek // Unfallchirurg. - 2017. Vol. 120 (8). - P. 658-666. — DOI: 10.1007/s00113-017-0366-6.

12. Healing Complications Are Common After Locked Plating for Distal Femur Fractures / Ch. E. Henderson, T. J. Lujan, L. L. Kuhl [et al.] // Clinical Orthopaedics and Related Research. - 2011. - Vol. 469 (6). - P. 1757-1765. DOI: $10.1007 / \mathrm{s} 11999-011-1870-6$.

13. Outcomes of the Ilizarov frame use in elderly patients / E. Iliopoulos, N. Morrissey, S. Cho, A. Khaleel // Journal of Orthopaedic Science. - 2017. - Vol. 22 (4). - P. 783-786. DOI: $10.1016 /$ j.jos.2017.03.002.

14. Johnson E. E. Failure of LCP condylar plate fixation in the distal part of the femur / E. E. Johnson // The Journal Bone and Joint Surgery. Am. — 2006. — Vol. 88 (11). — P. 2539-2541.

15. Jupiter J. B. The management of nonunion and malunion of the distal humerus-a 30-year experience / J. B. Jupiter // Journal of Orthopaedic Trauma. - 2008. - Vol. 22 (10). P. 742-750. — DOI: 10.1097/BOT.0b013e318188d634.
16. Temporary joint-spanning external fixation before internal fixation of open intra-articular distal humeral fractures: a staged protocol / P. Kloen, D. L. Helfet, D. G. Lorich [et al.] // Journal of Shoulder and Elbow Surgery. — 2012. - Vol. 21 (10). P. 1348-1356. — DOI: 10.1016/j.jse.2012.01.015.

17. Lee D. J. External fixation versus open reduction with locked volar plating for geriatric distal radius fractures / D. J. Lee, J. C. Elfar // Geriatric Orthopaedic Surgery \& Rehabilitation. - 2014. Vol. 5 (3). — P. 141-143. — DOI: 10.1177/2151458514542337.

18. Link B. C. Current Concepts in Fractures of the Distal Femur B. C. Link, R. Babst // Acta chirurgiae orthopaedicae et traumatologiae Cechoslovaca. - 2012. - Vol. 79. - P. 11-20.

19. Tibial pilon fractures: a review of incidence, diagnosis, treatment, and complications / C. Mauffrey, G. Vasario, B. Battiston [et al.] // Acta Orthopædica Belgica. — 2011. — Vol. 77 (4). P. 432-440.

20. Complications of definitive open reduction and internal fixation of pilon fractures of the distal tibia / P. A. McCann, M. Jackson, S. T. Mitchell, R. M. Atkins // International Orthopaedics. - 2011. — Vol. 35 (3). - P. 413-418. DOI: $10.1007 / \mathrm{s} 00264-010-1005-9$.

21. Nieto H. Limits of internal fixation in long-bone fracture / H. Nieto, C. Baroan // Orthopaedics \& Traumatology: Surgery \& Research. — 2017. — Vol. 103 (1S). - P. 61-66. DOI: $10.1016 /$ j.otsr.2016.11.006.

22. Treatment of high-energy pilon fractures using the ILIZAROV treatment / W. Osman, Z. Alaya, H. Kaziz [et al.] // The Pan African Medical Journal. — 2017. — Vol. 27. — Article ID : 199. — DOI: 10.11604/pamj.2017.27.199.11066.

23. Ramlee M. H. The use of external fixator for ankle and foot injuries management-a review on biomechanical perspective / M. H. Ramlee, A. Derus // Medical Devices and Diagnostic Engineering. - 2016. - Vol. 1 (1). - P. 5-10. DOI: 10.15761/MDDE.1000102.

24. External fixation versus ORIF for distal intra-articular tibia fractures / J. E. Richards, M. Magill, M. A. Tressler [et al.] // Orthopedics. - 2012. - Vol. 35 (6). - P. 862-867. DOI: $10.3928 / 01477447-20120525-25$.

25. Suksathien Y. Clinical study of a new design multifunction dynamic external fixator system for open tibial fracture / Y. Suksathien, R. Suksathien // Journal of the Medical Association of Thailand. - 2011. - Vol. 94 (9). - P. 1084-1088.

26. Ilizarov treatment of infected nonunions of the distal humerus after failure of internal fixation: an outcomes study / M. R. Brinker, D. P. O'Connor, C. C. Crouch [et al.] // Journal of Orthopaedic Trauma. - 2007. - Vol. 21 (3). - P. 178-184. DOI: 10.1097/BOT.0b013e318032c4d8.

27. Treatment of metaphyseal fractures of the tibia by the Ilizarov external fixator / J. Y. Caffiniere, J. M. Zeitoun, J. M. Segonds, F. Lacaze // Revue de chirurgie orthopedique et reparatrice de l'appareil moteur. - 1997. - Vol. 83 (2). - P. 123-132.

28. Analysis of the variables affecting outcome in fractures of the tibial pilon treated by open reduction and internal fixation / R. Carbonell-Escobar, J. C. Rubio-Suarez, A. Ibarzabal-Gil, E. C. Rodriguez-Merchan // Journal of Clinical Orthopaedics and Trauma. - 2017. — Vol. 8 (4). P. 332-338. DOI: $10.1016 /$ j.jcot.2017.05.014.

29. Darouiche R. O. (Treatment of infections associated with surgical implants / R. O. Darouiche // The New England Journal of Medicine. - 2004. - Vol. 350 (14). - P. 1422-1429.

30. Postoperative infection in patients undergoing inspection of orthopedic damage due to external fixation / N. O. Foni, F. A. Batista, L. H. Rossato [et al.] // Revista Brasileira de Ortopedia. - 2015. - Vol. 50 (6). - P. 625-630. DOI: $10.1016 /$ j.rboe.2015.10.011.

31. Hybrid external fixation in the treatment of tibial pilon fractures: A retrospective analysis of 162 fractures / V. N. Galante, G. Vicenti, G. Corina [et al.] // Injury. — 2016. — Vol. 47 (4). - 
P. 131-137. - DOI: 10.1016/j.injury.2016.07.045.

32. McKee M. Open intercondylar fractures of the distal humerus: management using a mini-external fixator construct / M. McKee // Journal of Shoulder and Elbow Surgery. — 2009. Vol. 18 (3). - P. 53-54. — DOI: 10.1016/j.jse.2009.01.032.

33. Distal tibial pilon fractures (AO/OTA type $\mathrm{B}$, and $\mathrm{C}$ ) treated with the external skeletal and minimal internal fixation method/ S. Milenkovic, M. Mitkovic, I. Micic [et al.] // Vojnosanitetski pregled. - 2013. - Vol. 70 (9). - P. 836-841.

34. Distal femur nonunion patients can expect good outcomes/ A. Monroy, A. Urruela, P. Singh [et al.] // The journal of knee surgery. - 2014. - Vol. 27 (1). — P. 83-87. — DOI: 10.1055/s0033-1349402.
35. Analysis of risk factors of the postoperative complications of surgical treatment of ankle fractures in the elderly: A series of 477 patients / Y. Varenne, J. Curado, Y. Asloum [et al.] // Orthopaedics \& Traumatology: Surgery\&Research. — 2016. Vol. 102 (4). — P. 245-248. — DOI: 10.1016/j.otsr.2016.03.004.

36. The articular fracture of the lower limb / O. Weber, M. C. Muller, H. Goost [et al.] // Zeitschrift fur Orthopadie und Unfallchirurgie. — 2009. — Vol. 147 (3). - P. 298-305. — DOI: 10.1055/s2008-1039265.

37. The treatment of infected tibial nonunion by bone transport using the Ilizarov external fixator and a systematic review of infected tibial nonunion treated by Ilizarov methods / P. Yin, Q. Zhang, Z. Mao [et al.] // Acta Orthopædica Belgica. 2014. - Vol. 80 (3). - P. 426-435.

\section{ОПТИМИЗАЦИЯ ТАКТИКИ ЛЕЧЕНИЯ \\ ПЕРЕЛОМОВ ДИСТАЛЬНЫХ МЕТАЭПИФИЗОВ ДЛИННЫХ КОСТЕЙ НА ОСНОВЕ БИОЛОГИЧЕСКИХ ПРИНЦИПОВ}

\section{I. Г. Бець}

ДУ «Інститут патології хребта та суглобів ім. проф. М. І. Ситенка НАМН України», Харків

$\triangle$ Iryna Bets, PhD in Traumatology and Orthopaedics: betsirina1984@gmail.com

\section{ВНИМАНИЮ АВТОРОВ}

В связи с тем, что журнал внесен в Перечень научных специализированных изданий, в которых могут публиковаться результаты диссертационных работ, обращаем ваше внимание на необходимость указывать на титульном листе статьи на трех языках (рус., укр., англ.)следующие сведения: 1) фамилию, имя, отчество; 2) название статьи; 3) официальное название учреждения и отдела (кафедры, лаборатории), в котором выполнена работа. Фамилия автора и учреждение, в котором он(она) работает, должны сопровождаться одним цифровым индексом.

Кроме того, на отдельном листе просим предоставить сведения о каждом из авторов: 1) фамилию, имя и отчество; 2) должность; 3) полный почтовый служебный адрес и e-mail; 4) номер служебного телефона и факса. Необходимо указать контактное лицо.

При подготовке статьи следует соблюдать правила для авторов, публикуемые в журнале и на сайте otp-journal.com.ua. 